\title{
REFERENCES
}

Borei, H. (1945). Ark. Kemi Min. Geol. 20 A, no. 8.

Haas, E. (1943). J. biol. Chem. 148, 481.

Keilin, D. \& Hartree, E. F. (1938). Proc. roy. Soc. B, 125, 171.

Keilin, D. \& Hartree, E. F. (1940). Proc. roy. Soc. B, 129, 277.

Keilin, D. \& Hartree, E. F. (1945). Biochem. J. 39, 289.

Keilin, D. \& Hartree, E. F. (1947a). Biochem. J. 41, 500.
Keilin, D. \& Hartree, E. F. (1947b). Biochem. J. 41, 503.

Keilin, D. \& Hartree, E. F. (1949). Biochem. J. 44, 205.

Lineweaver, H. \& Burk, D. (1934). J. Amer. chem. Soc. 56, 658.

Slater, E. C. (1948). Biochem. J. 43, xx.

Slater, E. C. (1949a). Biochem. J. 45, 1.

Slater, E. C. (1949b). Biochem. J. 45, 8.

\section{Extrahepatic Lipid Synthesis}

\author{
By G. POPJÁK ANd MARIE-LOUISE BEECKMANS \\ The National Institute for Medical Research, The Ridgeway, London, N.W. 7
}

(Received 3 March 1950)

It is generally thought that in the animal body the liver is the principal organ concerned with both the synthesis and degradation of fatty substances. Except for a recent article by Masoro, Chaikoff \& Dauben (1949) there is no definite evidence that fatty acids or cholesterol can be synthesized outside the liver in the adult animal, although Waelsch, Sperry \& Stoyanoff $(1940 b)$ have demonstrated the synthesis of fatty acids and cholesterol in the brain of growing rats during myelination. Masoro et al. (1949) noted the appearance of ${ }^{14} \mathrm{C}$-labelled fatty acids after the injection of ${ }^{14} \mathrm{C}$-labelled glucose in liverless animals whose intestinal tracts were also removed. They inferred that the conversion of carbohydrate into fat occurred probably in the adipose tissues. Srere, Chaikoff \& Dauben (1948) quoted some unpublished experiments in which conversion of acetate to cholesterol was demonstrated in the liverless rat; they did not, however, state in which organ the conversion occurred.

In this article results obtained with the aid of deuterium (D) and ${ }^{14} \mathrm{C}$-labelled acetate are recorded, and it is shown that internal organs other than the liver synthesize both fatty acids and cholesterol.

\section{METHODS AND MATERIAL}

Female rabbits (2-3 kg.) were the experimental animals. All except one were pregnant. The results obtained on the foetuses of these animals have already been recorded (Popják \& Beeckmans, $1949 a, b ; 1950)$.

The rabbits were given by intravenous injection an amount of pure $\mathrm{D}_{2} \mathrm{O}$ (made isotonic with $\mathrm{NaCl}$ ) sufficient to bring the concentration of $\mathrm{D}_{2} \mathrm{O}$ in the body fluids to a level of $1.5 \%$; the drinking water was then replaced by $2 \% \mathrm{D}_{2} \mathrm{O}$ in tap water. The concentration of $\mathrm{D}_{2} \mathrm{O}$ in the body fluids was thus maintained constant at a level of about $1.5 \%$. The animals were given the heavy water for 1-12 days. It has been shown by the extensive studies of Schoenheimer and his collaborators and others (see Schoenheimer, 1941), that the rate of incorporation of $\mathrm{D}$ from the body water into fatty acids and cholesterol under such experimental conditions may be used as a measure of the turnover of these substances in the tissues.

$\mathrm{Na}$ acetate labelled in the carboxyl $\mathrm{C}$ with ${ }^{14} \mathrm{C}$ was injected intravenously, two or three injections being given daily for 1-4 days. The total dose of ${ }^{14} \mathrm{C}$ was $50-100 \mu \mathrm{c}$. The specific activity of the injected acetate was $100 \mu \mathrm{c} .{ }^{14} \mathrm{C} / 8.6 \mathrm{mg}$. of anhydrous $\mathrm{Na}$ acetate.

The animals, under nembutal-ether anaesthesia, were killed by bleeding from the aorta. The blood was heparinized. The $\mathrm{D}$ and ${ }^{14} \mathrm{C}$ contents of the fatty acids and cholesterol were examined in the liver, plasma, gastro-intestinal tract, lungs, kidneys, spleen, heart, skeletal muscle, adrenals, ovaries and brain. The gastro-intestinal tract was washed clean with warm water before extraction. Data will be presented only for those organs in which the isotope concentrations of the lipids exceeded those found in the liver, as this proves extrahepatic synthesis. All experimental evidence tends to show that plasma lipids are derived from the liver (see Discussion, p. 236); therefore an isotope concentration higher in tissue lipids than in plasma lipids may also be regarded as a proof of the extrahepatic origin of the former.

The methods of extraction and fractionation of lipids and the methods of isotope determinations were those already described (Popják \& Beeckmans, 1950). In the one experiment, in which the free and esterified cholesterol were examined separately (see Table 2), the free cholesterol was precipitated as the digitonide from the acetone supernatant obtained after the precipitation of phospholipins. After removal of the free cholesterol as the digitonide and of the excess digitonin, the solution containing glycerides and cholesteryl esters was saponified. The unsaponifiable matter was separated from the soaps by extraction with light petroleum (b.p. 40-60 ) and the cholesterol from the esters precipitated as the digitonide.

The $D$ content of the substances is expressed as a percentage of that found in the body water. The ${ }^{14} \mathrm{C}$ content is given in the Tables as $\mu \mathrm{c} . / \mathrm{mg}$. substance. Under our conditions of radioactive assay a substance which contained $1 \times 10^{-3} \mu \mathrm{c}$./mg. gave $1800 \mathrm{counts} / \mathrm{min}$. in an 'infinite thickness' sample of area 2 sq.cm. 


\section{RESULTS}

\section{Extrahepatic synthesis of cholesterol}

The accumulation of $D$ in cholesterol extracted from the small intestine, liver and skeletal muscle of rabbits whose body water was enriched with $\mathrm{D}_{2} \mathrm{O}$ is shown in Fig. 1. The data show that cholesterol is

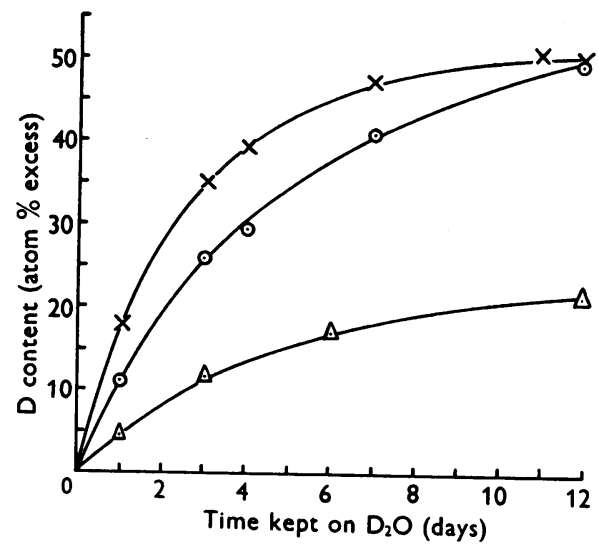

Fig. 1. Uptake of deuterium from body water into cholesterol of small intestine, liver and skeletal muscle in rabbits whose body water was enriched with $\mathrm{D}_{2} \mathrm{O}$ for 1-12 days. The deuterium content of cholesterol (atom \% excess) is expressed as a percentage of that found in body water. $x$, intestine; $\odot$, liver; $\Delta$, skeletal muscle.

formed in the intestine independently from the liver since the $D$ content of the sterol in the former rose more rapidly than in the latter. The $D$ content of the cholesterol in both tissues tended to a maximum value of $50 \%$ of that in the body water and appears to have been reached in 12 days. The half-life of cholesterol, i.e. the time required to obtain one-half of the maximum isotope concentration was 3 days in the liver and about 1.5 days in the intestine. During these intervals at least one-half of the tissue cholesterol must have been replaced by newly synthesized cholesterol. From the average cholesterol content of the liver and small intestine and the above half-lives it is calculated that in the liver of adult rabbits approximately $50 \mathrm{mg}$. and in the intestine $100 \mathrm{mg}$. of cholesterol/100 g. tissue are synthesized per day. The latter estimate necessarily applies only to the intestine as a whole, with all its structural layers. It seems very probable that synthesis of cholesterol in the intestine takes place mainly in the mucosa and that if the mucosa had been extracted separately from the muscularis, an even shorter half-life might have been found for the cholesterol in the former, than for the organ as a whole.

As a comparison, Fig. 1 also shows the rate of accumulation of $\mathrm{D}$ in the cholesterol of skeletal muscle. This is approximately the same as that published for whole mice (Rittenberg \& Schoenheimer, 1937). It is impossible to say from the data whether cholesterol in the muscle is synthesized there or whether it is transported from the liver via the blood stream since the D content of the substance in the muscle was appreciably less than in the liver. The half-life does not seem to have been reached yet in 12 days.

The above results are strengthened further by those obtained in animals injected with $\mathrm{CH}_{3}{ }^{14} \mathrm{CO}_{2} \mathrm{Na}$. These are summarized in Table 1 . It has been shown by Bloch \& Rittenberg $(1942 a, b)$ that acetate is a specific precursor of cholesterol.

The results show that cholesterol extracted from the small intestine contained three to five times more ${ }^{14} \mathrm{C}$ than cholesterol in the liver. Also the ovarian cholesterol had a higher specific activity than the liver cholesterol, indicating that cholesterol is synthesized in this organ also. It should be pointed out that the animals recorded under Exps. 1-6 were pregnant and their ovaries contained corpora lutea. The cholesterol in these ovaries contained almost twice as much, or even more, ${ }^{14} \mathrm{C}$ than the liver cholesterol, whereas in the ovary of the non-pregnant animal (Exp. 7) the specific activity of the cholesterol exceeded that of the liver cholesterol by only $30 \%$.

In Exp. 2, Table 1, free and esterified cholesterol were obtained separately from the liver and small

Table 1. ${ }^{14} \mathrm{C}$ content of tissue total cholesterol (except when otherwise specified) in rabbits injected repeatedly with $\mathrm{CH}_{3}{ }^{14} \mathrm{COONa}$

( ${ }^{14} \mathrm{C}$ content expressed as $1 \times 10^{-4} \mu \mathrm{c} . / \mathrm{mg}$. cholesterol.)

\begin{tabular}{|c|c|c|c|c|c|c|}
\hline Exp. no. & Liver & Plasma & $\begin{array}{c}\text { Small } \\
\text { intestine }\end{array}$ & Ovary & $\begin{array}{l}\text { Total } \\
{ }^{14} \mathrm{C} \text { dose } \\
(\mu \mathrm{c} .)\end{array}$ & $\begin{array}{l}\text { Time of killing } \\
\text { after lst injection } \\
(\mathrm{hr} .)\end{array}$ \\
\hline $\begin{array}{l}1 \\
2\end{array}$ & $\begin{array}{l}1 \cdot 10 \\
2 \cdot 12 \text { (free) } \\
1 \cdot 43 \text { (ester) }\end{array}$ & $\begin{array}{l}1.08 \\
1.80\end{array}$ & $\begin{array}{l}5 \cdot 75 \\
6 \cdot 18 \text { (free) } \\
1 \cdot 80 \text { (ester) }\end{array}$ & $\begin{array}{l}2 \cdot 74 \\
2 \cdot 50\end{array}$ & $\begin{array}{l}100 \\
100\end{array}$ & $\begin{array}{l}19 \\
20\end{array}$ \\
\hline $\begin{array}{l}3 \\
\mathbf{4} \\
\mathbf{5} \\
\mathbf{6} \\
\mathbf{7}\end{array}$ & $\begin{array}{l}1.30 \\
0.80 \\
0.65 \\
0.90 \\
0.70\end{array}$ & $\begin{array}{l}1.25 \\
0.65 \\
0.63 \\
0.46 \\
0.62\end{array}$ & $\begin{array}{l}\mathbf{7 \cdot 4 5} \\
\mathbf{3} \cdot \mathbf{3 0} \\
\mathbf{3} \cdot \mathbf{6 7} \\
\mathbf{2} \cdot 94 \\
\mathbf{2} \cdot 12\end{array}$ & $\begin{array}{l}-\overline{1.46} \\
1.70 \\
1.57 \\
1.00\end{array}$ & $\begin{array}{r}100 \\
50 \\
50 \\
50 \\
50\end{array}$ & $\begin{array}{l}22 \\
24 \\
30 \\
48 \\
96\end{array}$ \\
\hline
\end{tabular}


intestine; the specific activity of the free cholesterol was much higher, especially in the intestine, than that of the esterified cholesterol. In the same experiment the total cholesterol of the wall of the stomach and of the large intestine was also examined; the former contained $3.21 \times 10^{-4}$ and the latter $1.40 \times 10^{-4} \mu \mathrm{c} .{ }^{14} \mathrm{C} / \mathrm{mg}$. as against $1.89 \times 10^{-4} \mu \mathrm{c} . / \mathrm{mg}$. total cholesterol in the liver.

A further point worth mentioning in connexion with the data of Table 1 is that the isotope content of plasma cholesterol never exceeded, but was usually slightly less than, that of liver cholesterol.

\section{Extrahepatic synthesis of fatty acids}

The tissue lipids were fractionated into phospholipins and glycerides and their fatty acids studied separately. This was done in order to see if some indication might be obtained of the respective parts these two fatty acid compounds may play in fat metabolism. We are not aware of published accounts of any possible differences in rates of synthesis of phospholipins and glyceride fatty acids. The published data on fatty acid synthesis in animals have been obtained on total fatty acids. The 'glyceride' fatty acids in our material contained also a small quantity of fatty acids derived from cholesteryl esters. The amounts of these, however, in the tissues are small compared with the true glyceride fatty acids and thus it is thought that this heterogeneity would not influence the results significantly.

Fig. 2 shows the uptake of $D$ into glyceride and phospholipin fatty acids in the liver and intestine of rabbits whose body water was enriched with $\mathrm{D}_{2} \mathrm{O}$ for 1-12 days. In the liver there was no significant difference between the $\mathrm{D}$ content of glyceride and phospholipin fatty acids on any particular day. In the small intestine, however, the uptake of D into phospholipin fatty acids was about twice as fast as into glyceride fatty acids. Moreover, the phospholipin fatty acids in the intestine contained significantly higher concentrations of $D$ than in the liver fatty acids, indicating extrahepatic formation.
These results are confirmed by data obtained on animals injected with $\mathrm{CH}_{3}{ }^{14} \mathrm{CO}_{2} \mathrm{Na}$ (Table 2). It has been shown by Rittenberg \& Bloch $(1944,1945)$ that acetate carbon is utilized not only for cholesterol but for fatty acid synthesis also.

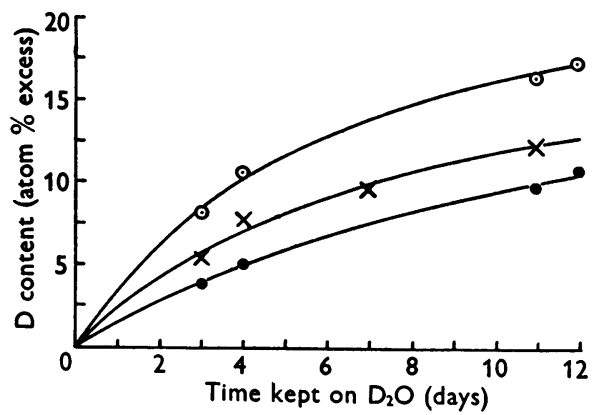

Fig. 2. Uptake of deuterium from body water into phospholipin and glyceride fatty acids of small intestine and liver in rabbits whose body water was enriched with $\mathrm{D}_{2} \mathrm{O}$ for 1-12 days. The deuterium content of fatty acids (atom $\%$ excess) is expressed as a percentage of that found in body water. $\odot$, intestine, phospholipin fatty acids; 0 , intestine, glyceride fatty acids; $x$, liver, phospholipin and glyceride fatty acids (the $\mathrm{D}$ content of the two types of fatty acids in the liver was the same).

In the liver, except for the two experiments of the shortest duration (Table 2, Exps. 1 and 2), the phospholipin and glyceride fatty acids contained about equal amounts of ${ }^{14} \mathrm{C}$. In two experiments of 19 and $20 \mathrm{hr}$. duration the phospholipin fatty acids, however, were richer in the isotope. In the small intestine the phospholipin fatty acids contained about six to nine times and the glyceride fatty acids about two to three times as much ${ }^{14} \mathrm{C}$ as the corresponding acids in the liver proving unequivocally the intestinal synthesis of fatty acids. In Exp. 2 (Table 2) the fatty acids of the wall of the stomach and large intestine were also analysed; in the former the specific activity of the phospholipin and glyceride fatty acids was $23.1 \times 10^{-5}$ and $7.84 \times 10^{-5} \mu \mathrm{c}$. ${ }^{14} \mathrm{C} / \mathrm{mg}$. respectively and in the latter $16.8 \times 10^{-5}$ and

Table 2. ${ }^{14} \mathrm{C}$ content of phospholipin and glyceride fatty acids of liver, intestine and lung of rabbits injected repeatedly with $\mathrm{CH}_{3}{ }^{14} \mathrm{COONa}$

( ${ }^{14} \mathrm{C}$ content expressed as $1 \times 10^{-5} \mu \mathrm{c} . / \mathrm{mg}$. fatty acid.)

\begin{tabular}{|c|c|c|}
\hline \multirow[b]{2}{*}{$\begin{array}{c}\text { Exp. } \\
\text { no. }\end{array}$} & \multicolumn{2}{|c|}{ Liver } \\
\hline & $\begin{array}{l}\text { Phospho- } \\
\text { lipin } \\
\text { fatty } \\
\text { acids }\end{array}$ & $\begin{array}{l}\text { Glyceride } \\
\text { fatty } \\
\text { acids }\end{array}$ \\
\hline $\begin{array}{l}1 \\
2 \\
3 \\
4 \\
5 \\
6\end{array}$ & $\begin{array}{l}\mathbf{4} \cdot 40 \\
8 \cdot 63 \\
2 \cdot 53 \\
1 \cdot 11 \\
1 \cdot 30 \\
1 \cdot 68\end{array}$ & $\begin{array}{l}2 \cdot 81 \\
5 \cdot 39 \\
2 \cdot 66 \\
1 \cdot 30 \\
1 \cdot 13 \\
2 \cdot 00\end{array}$ \\
\hline
\end{tabular}

$\begin{array}{cc}\begin{array}{c}\text { Phospho- } \\ \text { lipin } \\ \text { fatty }\end{array} & \begin{array}{c}\text { Glyceride } \\ \text { fatty }\end{array} \\ \text { acids } & \text { acids } \\ 21 \cdot 80 & 10 \cdot 00 \\ 31 \cdot 48 & 17 \cdot 13 \\ 29 \cdot 38 & 11 \cdot 52 \\ 7 \cdot 62 & 2 \cdot 91 \\ 9 \cdot 61 & 4 \cdot 10 \\ 9 \cdot 41 & 3.51\end{array}$

\begin{tabular}{|c|c|}
\hline \multicolumn{2}{|c|}{ Lung } \\
\hline $\begin{array}{l}\text { Phospho- } \\
\text { lipin } \\
\text { fatty } \\
\text { acids }\end{array}$ & $\begin{array}{l}\text { Glyceride } \\
\text { fatty } \\
\text { acids }\end{array}$ \\
\hline $\begin{array}{l}132 \cdot 0 \\
155 \cdot 5 \\
118 \cdot 6\end{array}$ & $\begin{array}{l}18 \cdot 5 \\
39 \cdot 6 \\
12 \cdot 36\end{array}$ \\
\hline 一 & 一 \\
\hline 二 & - \\
\hline
\end{tabular}

Total
14 dose
$(\mu \mathrm{c})$
100
100
100
50
50
50

Time of killing after lst injection (hr.) 
$4.0 \times 10^{-5} \mu \mathrm{c} .{ }^{14} \mathrm{C} / \mathrm{mg}$. fatty acids respectively. Thus the phospholipin fatty acids contained, even in the wall of the stomach and large intestine, more isotope than the fatty acids in the liver. Hence it must be concluded that fatty acid synthesis occurs along the whole gastro-intestinal tract. The possible significance of the observed differences between phospholipins and glycerides will be discussed later.

A rather unexpected finding in these experiments was the extremely high degree of utilization of acetate carbon for fatty acid synthesis in the lung. It may be seen from the figures in Table 2 that the phospholipin fatty acids in the lung contained 30-45 times and the glyceride fatty acids four to six times more ${ }^{14} \mathrm{C}$ than the corresponding fatty acids in the liver. Whatever the biochemical mechanism of the incorporation of ${ }^{14} \mathrm{C}$ into the lung fatty acids from the administered acetate may be, the results can mean only the independent synthesis of fatty acids in the lung.

\section{DISCUSSION}

The results presented show that the liver of the adult animal is not the only organ concerned with cholesterol and fatty acid synthesis. Up to now the only proven site of cholesterol synthesis in the intact adult animal was the liver (Bloch, Borek \& Rittenberg, 1946), although Srere et al. (1948) have recently demonstrated the formation of cholesterol in vitro by surviving adrenal slices. Fatty acid and cholesterol synthesis in the extrahepatic tissues of the foetus was found to be the major source of foetal lipids (Popják \& Beeckmans, 1950). In the present investigation the incorporation of $D$ from the body water into the cholesterol of the intestine was more rapid than into the cholesterol of the liver. This finding is taken as proof of an extrahepatic synthesis. After the administration of ${ }^{14} \mathrm{C}$-labelled acetate the specific activity of the cholesterol in the small intestine, in the stomach and in the ovaries was higher than in the plasma or liver. These results fully support and extend those obtained with the aid of $D$. The significantly higher specific activity of the free cholesterol than that of the esterified cholesterol (Table 1, Exp. 2) must mean that cholesterol is synthesized in the free form and esterified subsequently. In order to study, therefore, the true rate of synthesis of cholesterol in the tissues one should separate free cholesterol from the esterified form.

While the results show that organs other than the liver can synthesize cholesterol, yet it appears that the liver is the main, if not the only source of plasma lipids. It has been shown by Fishler, Entenman, Montgomery \& Chaikoff (1943) and by Entenman, Chaikoff \& Zilversmit (1946) that plasma phospholipins originate from the liver. This is probably true for plasma cholesterol also. In the experiments presented the ${ }^{14} \mathrm{C}$ content of plasma cholesterol never exceeded that of the liver in spite of the fact that cholesterol of much higher specific activity than in the liver was found in the intestine. It is, therefore, unlikely that the intestine contributes significantly to plasma cholesterol.

It is of interest to mention that Scott, Glover \& Morton (1949) reported at the lst International Congress of Biochemistry the presence of 7-dehydrocholesterol in the intestinal contents of certain species (guinea pig, rat, ox) and adduced evidence for the existence in the intestine of a cholesteroldehydrogenase the action of which is reversible. Thus cholesterol synthesized in the intestine might be the source of provitamin $D_{3}$.

Waelsch, Sperry \& Stoyanoff $(1940 a)$ found in adult rats whose body water was enriched with $\mathrm{D}_{2} \mathrm{O}$ the highest concentration of $\mathrm{D}$ in liver fatty acids. Although the values for intestinal fatty acids were lower than those of the liver, nevertheless they were sufficiently high to enable the authors to emphasize the active role of the intestine in fat metabolism. In our experiments $D$ concentrations far in excess of those found in liver fatty acids were observed in the intestinal phospholipin fatty acids, offering conclusive proof for their extrahepatic synthesis. Since, however, the glyceride fatty acids in the intestine contained much less $D$ than the liver fatty acids, it is very probable that the failure of Waelsch et al. (1940 a) to demonstrate definitely with the aid of D the intestinal formation of fatty acids is due to the fact that they studied total fatty acids. It has been shown in the present investigation with the aid of $\mathrm{CH}_{3}{ }^{14} \mathrm{CO}_{2} \mathrm{Na}$ that even glyceride fatty acids are synthesized in the intestine.

It should be pointed out that a discrepancy exists between the results obtained with $D$ and those obtained after the administration of $\mathrm{CH}_{3}{ }^{14} \mathrm{CO}_{2} \mathrm{Na}$. The rate of incorporation of $\mathrm{D}$ into the phospholipin fatty acids of the small intestine was almost twice as fast as into liver fatty acids, yet six to nine times as much ${ }^{14} \mathrm{C}$ was found in the former than in the latter. Similarly, the D data indicated a slower turnover rate for the glyceride fatty acids in the intestine than in the liver, yet two to three times as much ${ }^{14} \mathrm{C}$ appeared in the former than in the latter. This anomaly might be explained by the assumption that the injected acetate was diluted by endogenous acetate to different degrees in the liver and intestine respectively. If the amount of endogenous acetate in the liver is greater than in the intestine, then the specific activity of the total acetate would be lower in the former than in the latter. Hence the products of synthesis from acetate would have a higher specific activity in the intestine than in the liver. This might be the case even if the turnover of the substances in the intestine were equal to or even less than the turnover in the liver. Another possibility 
to be considered is that the fat precursors in the liver and intestine are not identical.

Attention should be drawn to certain species differences which are apparent when the results of this paper are compared with those of other publications. Most of the investigations of fat metabolism with isotopic tracers have so far been carried out on rats. Most striking differences appear to exist between the turnover times of liver cholesterol and fatty acids in the rat and rabbit. In the former animal the half-life of liver cholesterol was estimated to be about 5-10 days (Bloch et al. 1946) and that of the liver fatty acids 1.9 days (Stetten \& Boxer, 1944). In the rabbit the half-life of liver cholesterol was 3 days; the half-life of liver fatty acids, on the other hand, was not yet reached in 11-12 days assuming that the maximum $D$ content of mixed fatty acids (saturated + unsaturated) in the rabbit is about $38 \%$ of that found in the body water just as in the rat (Rittenberg \& Schoenheimer, 1937; Stetten \& Boxer, 1944).

The significantly higher isotope content of the phospholipin fatty acids as compared with that of the glyceride fatty acids (at least in the intestine and lung) throws some new light on the physiological significance of phospholipins whose function is as yet not clear. The simplest interpretation of the results presented is that the phospholipins are primarily connected with the synthesis of fatty acids rather than with their transport, as has been suggested (for review of this subject see Bloor, 1943). It seems probable that the phospholipin fatty acids then exchange with glyceride fatty acids. In the liver no difference was found between the $\mathrm{D}$ content of phospholipin and glyceride fatty acids. The earliest observation was, however, made only after 3 days of $\mathrm{D}_{2} \mathrm{O}$ administration. When ${ }^{14} \mathrm{C}$-labelled acetate was given to the animals for 19 and $20 \mathrm{hr}$. the phospholipin fatty acids in the liver also were richer in the isotope than the glyceride fatty acids; on the other hand, in experiments of longer duration, there were no significant differences in the ${ }^{14} \mathrm{C}$ contents of the two types of fatty acids. These results might mean that in the liver there is a rapid equilibrium between phospholipin and glyceride fatty acids; in the intestine and lung, however, this equilibrium might be established only relatively slowly.

The significance of the astonishingly high degree of utilization of acetate $\mathrm{C}$ for fatty acid synthesis in the lung is not clear at present. It might be pointed out that it has been repeatedly observed (see Bloch, 1947) that acetate carbon is utilized to a greater extent for cholesterol than for fatty acid synthesis. It was found in the present experiments with labelled acetate that in all the organs, with the exception of the lung, the cholesterol contained more ${ }^{14} \mathrm{C}$ than any of the fatty acid fractions. In the lung, however, the reverse was true; moreover, the specific activity of the lung phospholipin fatty acids was even higher than that of the most active cholesterol found anywhere in the body. The specific activity of the lung cholesterol, on the other hand, was lower than that of plasma or liver cholesterol, and hence it could not be determined whether the lung tissues can synthesize cholesterol. The high degree of utilization of acetate for fatty acid synthesis by the lung has been confirmed recently in a joint experiment (unpublished) with Dr S. J. Folley and Mr T. H. French on a lactating goat. Therefore the rabbit does not seem to be a unique species in this respect.

\section{SUMMARY}

1. Cholesterol and fatty acid synthesis was studied in rabbits with the aid of deuterium and ${ }^{14} \mathrm{C}$-labelled acetate.

2. It has been demonstrated that cholesterol is synthesized not only in the liver, but also in the intestine and ovaries. The probable source of plasma cholesterol is the liver.

3. Synthesis of fatty acids has been shown to occur along the entire gastro-intestinal tract and in the lung. The utilization of acetate for fatty acid synthesis was especially high in the latter organ.

4. In the intestine and lung the phospholipin fatty acids contained more isotope (deuterium or ${ }^{14} \mathrm{C}$ ) than the glyceride fatty acids, whereas in the liver the two types of fatty acids appear to come rapidly into equilibrium. The possible significance of these findings is discussed.

\section{REFERENCES}

Bloch, K. (1947). Physiol. Rev. 27, 574.

Bloch, K., Borek, E. \& Rittenberg, D. (1946). J. biol. Chem. 162,441 .

Bloch, K. \& Rittenberg, D. (1942a). J. biol. Chem. 143, 297.

Bloch, K. \& Rittenberg, D. (1942b). J. biol. Chem. 145, 625.

Bloor, W. R. (1943). Biochemistry of the Fatty Acids and their Compounds, the Lipids, p. 312. New York: Reinhold Publishing Corp.
Entenman, C., Chaikoff, I. L. \& Zilversmit, D. B. (1946). $J$. biol. Chem. 166, 15.

Fishler, M. C., Entenman, C., Montgomery, M. L. \& Chaikoff, I. L. (1943). J. biol. Chem. 150, 47.

Masoro, E. J., Chaikoff, I. L. \& Dauben, W. G. (1949). J. biol. Chem. 179, 1117.

Popják, G. \& Beeckmans, M.-I. (1949a). Biochem. J. 44, Xxxvi.

Popják, G. \& Beeckmans, M.-L. (1949b). Biochem. J. 44, xxxvii. 
Popják, G. \& Beeckmans, M.-L. (1950). Biochem. J. 46, 547.

Rittenberg, D. \& Bloch, K. (1944). J. biol. Chem. 154, 311.

Rittenberg, D. \& Bloch, K. (1945). J. biol. Chem. 160, 417. Rittenberg, D. \& Schoenheimer, R. (1937). J. biol. Chem. 121, 235.

Schoenheimer, R. (1941). The Dynamic State of Body Constituents, 2nd printing 1946. Cambridge, Mass.: Harvard University Press.
Scott, M., Glover, J. \& Morton, R. A (1949). 1 st Int. Biochem. Congr. Abstr., p. 10.

Srere, P. A., Chaikoff, I. L. \& Dauben, W. G. (1948). J. biol. Chem. 176, 829.

Stetten, DeW., jun. \& Boxer, G. E. (1944). J. biol. Chem. 155, 231.

Waelsch, H., Sperry, W. M. \& Stoyanoff, V. A. (1940a). J. biol. Chem. 135, 291.

Waelsch, H., Sperry, W. M. \& Stoyanoff, V. A. (1940b). J. biol. Chem. 135, 297.

\title{
The Breakdown of Adenosinetriphosphate in Extracts of Rabbit Muscle
}

\author{
BY BEVERLEY A. HUMPHREY AND G. F. HUMPHREY \\ The Department of Biochemistry, University of Sydney, Australia, and the Low Temperature Station \\ for Research in Biochemistry and Biophysics, University of Cambridge, and \\ Department of Scientific and Industrial Research
}

\section{(Received 10 May 1949)}

The claim, made in 1939 by Engelhardt \& Lyubimova, that the structural protein, myosin, was itself the enzyme responsible for the dephosphorylation of adenosinetriphosphate (ATP) in muscle, has since been often contested. No evidence could be found to the contrary by Bailey (1942) and Needham (1942), but Polis \& Meyerhof $(1946,1947)$ do not consider that myosin possesses, homogeneously, adenosinetriphosphatase (ATP-ase) activity. They contend that ATP-ase is absorbed on to myosin, like the potato apyrase in Kalckar's (1944) experiments. Various reviews of the controversy exist (Engelhardt, 1946; Polis \& Meyerhof, 1947).

However, apart from this ATP-ase, which may or may not be myosin itself, Sakov (1941), a member of the Engelhardt school, reported a distinct nonmyosin ATP-ase in aqueous extracts of muscle. The existence of such an enzyme is supported by calculations of Mommaerts \& Seraidarian (1947) and Braverman \& Morgulis (1948). The enzyme described by Sakov (1941) differs from myosin ATP-ase in solubility, $\mathrm{pH}$ optimum, and the extent of hydrolysis which it effects. It is not clear if this enzyme bears any relation to that reported by Lohmann (1928), who examined 'pyrophosphate' breakdown in a dilute salt extract of muscle, and described an ATP. ase with yet another set of properties. Sakov's (1941) non-myosin ATP-ase must further be compared with ATP-ases from tissues other than muscle, e.g. liver (Barrenscheen \& Lang, 1932), nervous tissue (Reis, 1937), sperm (Lardy, Hansen \& Phillips, 1945), potato (Kalckar, 1944) and various other animal tissues (Dubois \& Potter, 1943).

In this paper, some experiments on the ATP-ase in aqueous muscle extracts, prepared according to the method of Sakov (1941), were performed with a view to determining if the Sakov enzyme can, indeed, be considered distinct from myosin ATP-ase, and if it can be compared with ATP-ase from myosin-free sources.

\section{METHODS}

Incubations were carried out at either 25 or $37^{\circ}$; in all cases the reaction mixtures without the enzyme were incubated first for a few minutes and then the enzyme, at the required temperature, was added. The control and experimental tubes were deproteinized with a final concentration of $5 \%$ $(w / v)$ trichloroacetic acid, and inorganic phosphate estimated by the method of Fiske \& Subbarow (1925), using either a Finlayson single photocell, or a Hilger Spekker absorptiometer. The increase in inorganic phosphate was found to parallel the decrease of $7 \mathrm{~min}$. $P$ (inorganic $P$ set free after $7 \mathrm{~min}$. at $100^{\circ}$ in the presence of $\mathrm{N}-\mathrm{HCl}$ ) in the reaction mixtures and therefore the ATP was undergoing simple hydrolysis.

ATP was prepared by the method of Needham (1942), and analysis for $\mathrm{N}$ and inorganic, hydrolysable and total $\mathbf{P}$ showed the purity to be over $95 \%$. Synthetic muscle adenylic acid was kindly donated by Dr T. R. Mann of the Molteno Institute, Cambridge. The $\mathrm{pH}$ of the experiments was controlled with the glass electrode by determining the value of the mixture to be used, with water replacing the neutralized solution of ATP (or other substrate).

An attempt was made to keep as closely as possible to the quantities of material used by Sakov (1941), but since this author gives no details beyond indicating the range of the amounts used, the conditions adopted in this investigation differ slightly from experiment to experiment.

The enzyme was made by extracting chilled, fresh rabbit muscle twice with an equal volume of ice-cold water, and centrifuging after each extract; triple glass-distilled water was used for the majority of the extracts, solutions, and dialyses (the reaction mixtures contained less than $3 \times 10^{-6} \mathrm{M}$ total $\mathrm{Cu}$ ). The muscle was disintegrated either by grinding with sand or homogenizing in the Waring blender. The 